\title{
PENGEMBANGAN PERANGKAT PEMBELAJARAN MODEL PROBLEM BASED LEARNING DENGAN PENDEKATAN SAINTIFIK PADA MATERI PROKLAMASI KEMERDEKAAN INDONESIA UNTUK MENINGKATKAN PRESTASI BELAJAR SISWA KELAS XI SMKN 12 SURABAYA
}

\author{
Fatayat Ridlo Mintarsih \\ SMK Negeri 12 Surabaya
}

\begin{abstract}
Abstrak
Penelitian ini bertujuan untuk menghasilkan perangkat pembelajaran menggunakan model pembelajaran Problem Based Learning dengan pendekatan saintifik yang efektif dan berkualitas.Penelitian ini dilaksanakan dalam tiga tahap mengikuti rancangan 4-D model dari thiagarajan (1974). Tiga tahap tersebut adalah tahap pendahuluan (define), tahap perencanaan (design), dan tahap pengembangan (develop). Jenis penelitian ini adalah $R \& D$ dengan rancangan control group pre-test - post-test design, subyek penelitian ini adalah kelas 11 DKV-2 dengan jumlah siswa 30 sebagai kelas eksperimen dan kelas 11 DKV-1 dengan julah siswa 24 sebagai kelas control. Pengumpulan data penelitian diperoleh melalui kegiatan observasi, tes dan angket.Hasil penelitian diperoleh data sebagai berikut, pertama kualitas perangkat hasil pembelajaran yang meliputi hasil validasi RPP mencapai nilai rata-rata 3,39 (kategori baik), hasil validasi LKS mencapai nilai rata-rata 3,56 (kategori baik) hasil validasi handout mencapai nilai rata-rata 3,70 ( kategori baik) kedua pelaksanaan pembelajaran mencapai nilai rata-rata 3,3 (kategori baik), ketiga hasil belajar siswa tergolong kategori baik, Pada kompetensi sikap spiritual dan social tergolong baik, pada kompetensi pengetahuan menunjukkan bahwa validasi butir soal mencapai 3,78 (kategori baik) selain itu tingkat ketuntasan belajar pada kelas eksperimen mencapai 83,3\%, sedangkan tingkat ketuntasan pada kelas kontrol mencapai 73,6\%. Pada kommpetensi ketrampilan tergolong kategori baik. Keempat, respon siswa menunjukkan menunjukkan bahwa siswa senang mengikuti proses pembelajaran dengan model Problem Based Learning dengan pendekatan saintifik.
\end{abstract}

Kata Kunci:: Model Problem Based Learning, Proklamasi Kemerdekaan Indonesia, Prestasi Belajar Siswa

\begin{abstract}
This study aims to produce the quality and effective learning device using Problem Based Learning model with scientific approach.The study was conducted in three phases following the design of the 4-D mode of thiagarajan (1974). The three stages are the preliminary stage (define), the planning (design), and stage of development (develop). This type of research is the $R \& D$ to design the control group pre-test - post-test design, the subject of this research is class $11 \mathrm{DKV}-2$ with the number of students 30 as an experimental class and class 11 $D K V-1$ with the number students 24 as grade control. Collection of research data obtained through observation, tests and questionnaires.
\end{abstract}


The results were obtained the following data, first quality learning outcomes device that includes the results of the validation RPP reached an average 3.39 (both categories), the validation results of student worksheet reach an average of 3.56 (both categories) the results of the validation handout reaches an average of 3.70 (both categories) the implementation of learning reaches an average of 3.3 (both categories), the third student learning outcomes classified as either category, In the spiritual attitude and social competence quite good, the competence of knowledge suggests that a validation item about reaching 3.78 (both categories) than the level of mastery learning in the experimental class reached $83.3 \%$, while the level of completeness of the control class reached 73.6\%. On commpetency skills on classified quite good categories. Fourth, the response showed students showed that students enjoy participating in the learning process with a model Problem Based Learning with a scientific approach.

Keywords: Problem Based Learning Model, Proclamation of Indonesian Independence, Student Achievement

\section{PENDAHULUAN}

Kurikulum 2013 didesain berdasarkan pada budaya dan karakter bangsa, berbasis peradaban, dan berbasis pada kompetensi. Kurikulum 2013 menekankan pada dimensi pedagogik modern dalam pembelajaran, yaitu menggunakan pendekatan ilmiah. Pendekatan ilmiah (scientific appoach) meliputi mengamati, menanya, mencoba, mengolah, menyajikan, menyimpulkan, dan mencipta untuk semua mata pelajaran (Permendikbud, 2013).

Dalam pengajaran Sejarah , guru lebih banyak menyampaikan materi pelajaran sesuai dengan buku yang dipegang. Sementara dalam pembelajaran Sejarah siswa mendapat porsi lebih sedikit daripada guru bahkan guru harus dominan dalam kegiatan belajar mengajar

Belajar Sejarah berarti peserta didik mampu berpikir kritis dan mampu mengkaji setiap perubahan lingkungan, serta memiliki kesadaran akan perubahan dan nilai-nilai yang terkandung dalam setiap peristiwa sejarah. Pembelajaran Sejarah yang baik adalah pembelajaran yang mampu menumbuhkan kemampuan siswa melakukan konstruksi kondisi masa sekarang dengan mengkaitkan atau melihat masa masa lalu yang menjadi basis topik pembelajaran Sejarah.

Berdasarkan uraian di atas, maka penelitian ini memfokuskan tentang "Pengembangan Perangkat Pembelajaran Model Problem Based Learning (PBL) Dengan Pendekatan Saintifik pada Materi Proklamasi Kemerdekaan Indonesia Di Kelas XI SMK Negeri 12 Surabaya"..

Meskipun sudah banyak yang melakukan penelitian pembelajaran model problem based learning, namun di SMK negeri 12 masih banyak guru-guru (sejarah) yang belum menerapkannya. SMK Negeri 12 adalah salah satu sekolah yang sudah melaksanakan kurikulum 2013, maka penulis melakukan penelitian pembelajaran model problem based learning dengan pendekatan saintifik 
Rumusan masalah dalam penelitian ini adalah Bagaimanakah kualitas perangkat pembelajaran PBL dengan menggunakan model problem based learning dengan pendekatan saintifik unttuk meningkatkan prestasi belajar siswa kelas 11 SMKN 12 Surabaya pada materi Proklamasi Kemerdekaan Indonesia

Penelitian ini bertujuan untuk Untuk menganalisis apakah hasil belajar siswa yang diajarkan dengan pembelajaran problem based learning dengan pendekatan saintifik lebih baik dari pada hasil belajar siswa yang diajarkan dengan pembelajaran konvensional pada materi Proklamasi Kemerdekaan Indonesia di Kelas XI SMK

\section{Materi Proklamasi Kemerdekaan Indonesia}

Proklamasi Kemerdekaan Indonesia merupakan lahirnya Negara Republik Indonesia yang dilaksanakan pada tanggal 17 Agustus 1945. Pengembangan karakter tersebut bisa dilihat adanya konflik perbedaan pendapat antara Ir. Sukarno (golongan tua) dengan golongan pemuda pada situasi vacuum of power sampai diselenggarakannya Proklamasi kemerdekaan Indonesia serta bagaimana kondisi social politik bangsa Indonesia menjelang Proklamasi kemerdekaan Indonesia. Untuk membantu ketidakpahaman siswa dalam membentuk pengetahuannya tentang permasalahan yang akan diselidiki maka guru membimbing dengan memberikan pertanyaan-pertanyaan, aktivitas-aktivitas dan metodemetode dalam membangun pengetahuan sesuai dengan sudut pandang atau perspektif mereka sendiri yang didasarkan pada beberapa referensi dan tingat pengetahuan yang mereka peroleh.

Dalam materi Proklamasi

Kemerdekaan Indonesia peneliti memberikan permasalahan yang berkaitan dengan kehidupan siswa sehari-hari sebagai generasi muda penerus cita-cita proklamasi. Permasalahan yang diberikan adalah menipisnya semangat generasi muda masa kini dalam mengisi kemerdekaan

\section{Model Problem Based Learning}

Ibrahim dan Nur (2000:2)

mengemukakan bahwa Pembelajaran berbasis masalah tidak dirancang untuk membantu guru memberikan informasi sebanyak-banyaknya kepada siswa, melainkan dikembangkan untuk membantu siswa mengembangkan kemampuan berpikir, pemecahan masalah dan ketrampilan intelektual ; belajar menjadi pembelajar yang otonom dan mandiri melalui pengalaman nyata. Peran guru dalam pengajaran berbasis masalah adalah menyajikan masalah, mengajukan pertanyaan dan menfasilitasi penyelidikan dan dialog.

Sedangkan Moffit dalam Rusman (2012: 241) mengemukakan bahwa pembelajaran berbasis masalah merupakan suatu pendekatan pembelajaran yang menggunakan masalah dunia nyata sebagai suatu konteks bagi siswa untuk belajar berpikir kritis dan keterampilan pemecahan masalah serta untuk memperoleh konsep yang esensi dari materi pelajaran.

Sedangkan menurut Arends dalam Dyahwati dkk (2013:27) Pembelajaran berbasis masalah adalah pembelajaran yang berpusat pada siswa (student oriented). 
Pembelajaran berdasarkan masalah terutama dirancang untuk membantu siswa mengembangkan ketrampilan berpikir, ketrampilan menyelesaikan masalah, ketrampilan intelektualnya, sehingga menjadi pelajar yang mandiri dan otonom.

Arends dalam Trianto (2007:68) menyatakan bahwa PBL merupakan suatu pendekatan pembelajaran yang berfokus pada siswa dengan menggunakan masalah dalam dunia nyata yang bertujuan untuk menyusun pengetahuan siswa, melatih kemandirian dan rasa percaya diri, dan mengembangkan keterampilan berpikir siswa dalam pemecahan masalah.

Beberapa teori yang melandasi model pembelajaran berbasis masalah (problem based learning) diantaranya teori John Dewey Setiap orang telah mempunyai pengalaman dan pengetahuan di dalam dirinya serta pengalaman dan pengetahuan ini tertata dalam bentuk struktur kognitif Sugihartono dkk (2007: 105).

Teori David Ausubel Ausubel dalm Rusman (2012:244) membedakan antara belajar bermakna dengan belajar menghafal. Belajar bermakna merupakan proses belajar dimana informasi baru dihubungkan dengan struktur pengertian yang sudah dimiliki seseorang yang sedang belajar. Belajar menghafal, diperlukan bila seseorang memperoleh informasi baru dalam pengetahuan yang sama sekali tidak berhubungan dengan yang telah diketahuinya. Kaitannya dengan Pembelajaran berbasis masalah adalah mengaitkan informasi baru dengan struktur kognitif yang telah dimiliki siswa.

Sedangkan Vigotsky lebih menekankan pada aspek social pembelajaran. Menurut Vigotsky dalam Nur (20011:23) siswa memiliki dua tingkat perkembangan yang berbeda yaitu tingkat perkembangan actual dan potensial. Tingkat perkembangan actual adalah tingkat perkembangan intelektual idividu untuk mempelajari sesuatu atas upaya individu sendiri, sedangkan perkembangan potensial adalah tingkat perkembangan intelektual yang dapat dicapai individu dengan bantuan orang lain seperti guru, orang tua dan teman.

\section{Pendekatan Saintifik (scientific)}

Proses Pembelajaran dapat dipadankan dengan suatu pendekatan ilmiah. Dalam Kurikulum 2013 pendekatan saintifik diyakini sebagai titian emas perkembangan dan pengembangan sikap, ketrampilan dan Pengetahuan siswa.

Pembelajaran merupakan proses ilmiah, karena itu Kurikulum 2013 mengamanatkan esensi pendekatan ilmiah dalam pembelajaran. Proses pembelajaran pada Kurikulum 2013 untuk jenjang SMP dan SMA atau yang sederajat dilaksanakan menggunakan pendekatan ilmiah. Proses pembelajaran menyentuh tiga ranah, yaitu sikap, pengetahuan, dan keterampilan

(Kemendikbud:2013)

Penelitian yang dilakukan Edward (2011) menunjukkan bahwa pembelajaran saintifik selain dapat memberikan solusi terhadap guru dalam mengajar juga mampu memberikan peningkatan kemampuan siswa, hal ini disebabkan dengan adanya pengaruh kemampuan pedagogik pada siswa yang dikontruksi dengan sendirinya. Pendekatan saintifik merupakan pembelajaran yang berpusat pada 
siswa, sebagaimana proses pengalaman belajar yang ditempuh oleh siswa seperti, mengamati, menanya, mencari informasi, mengasosiasi, dan mengkomunikasi.

$$
\text { Proses pembelajaran }
$$

scientific merupakan perpaduan antara proses pembelajaran yang semula terfokus pada eksplorasi, elaborasi, dan konfirmasi dilengkapi dengan mengamati, menanya, menalar, mencoba, dan mengkomunikasikan (Kemendikbud, 2013).

\section{Pelaksanaan Kegiatan Pembelajaran Berbasis Masalah (problem based learning) dengan pendekatan saintifik (Scientific)}

Dalam metode saintifik tujuan utama kegiatan pendahuluan adalah memantapkan pemahaman siswa terhadap konsep-konsep yang telah dikuasai yang berkaitan dengan materi pelajaran baru yang akan dipelajari oleh siswa.

Kegiatan inti merupakan kegiatan utama dalam proses pembelajaran atau dalam proses penguasaan pengalaman belajar (learning experience) siswa. Kegiatan inti dalam pembelajaran adalah suatu proses pembentukan pengalaman dan kemampuan siswa secara terprogram yang dilaksanakan dalam durasi waktu tertentu. Kegiatan inti dalam metode saintifik ditujukan untuk terkonstruksinya konsep, hukum atau prinsip oleh siswa dengan bantuan dari guru melalaui langkah-langkah kegiatan yang diberikan di muka. Kegiatan penutup ditujukan untuk dua hal pokok. Pertama, validasi terhadap konsep, hukum atau prinsip yang telah dikonstruk oleh siswa. Kedua, pengayaan materi pelajaran yang dikuasai siswa.
Pelaksanaan pembelajaran didahului dengan penyiapan RPP yang dikembangkan oleh guru baik secara individual maupun kelompok yang mengacu pada Silabus. Dalam pembelajaran berbasis masalah, siswa dihadapkan pada masalah dunia nyata untuk memulai proses belajar dengan tujuan dapat merangsang berpikir tingkat tinggi untuk menyelesaikannya.

\section{Perangkat pembelajaran}

\section{a. Rencana \\ Pembelajaran (RPP)}

Pelaksanaan

Rencana pembelajaran adalah panduan langkah-langkah yang akan dilakukan guru dan siswa dalam melaksanakan kegiatan pembelajaran, yang tersusun dalam skenario persiapan mengajar berisi hal-hal yang harus dilakukan guru dan siswa dalam kegiatan pembelajaran. Rencana pembelajaran disusun untuk mempermudah guru dalam melaksanakan pembelajaran. Rencana Pembelajaran merupakan penjabaran silabus yang menggambarkan rencana prosedur dan pengorganisasian pembelajaran untuk mencapai suatu kompetensi dasar (Depdiknas, 2006a: 38).

Dalam rangka mengimplementasikan program pembelajaran tersebut, maka RPP harus disusun oleh guru. RPP ini digunakan sebagai pegangan bagi guru dalam melaksanakan pembelajaran baik di kelas, laboratorium, atau lapangan untuk setiap kompetensi dasar. Depdiknas (2006e: 1) menjelaskan bahwa, apa yang tertuang di dalam RPP memuat hal-hal yang langsung berkait dengan aktivitas pembelajaran dalam upaya pencapaian penguasaan suatu KD.

Kurikulum 2013 menggunakan modus pembelajaran 
langsung (direct instructional) dan tidak langsung (indirect instructional). Pembelajaran langsung adalah pembelajaran yang mengembangkan pengetahuan, kemampuan berpikir dan keterampilan menggunakan pengetahuan peserta didik melalui interaksi langsung dengan sumber belajar yang dirancang dalam silabus dan RPP. Dalam pembelajaran langsung peserta didik melakukan kegiatan mengamati, menanya, mengumpulkan informasi/mencoba, menalar/mengasosiasi, dan mengomunikasikan. Pembelajaran tidak langsung berkenaan dengan pengembangan nilai dan sikap yang terkandung dalam KI-1 dan KI-2 (Permendikbud no. 103 tahun 2014)

\section{b. Lembar Kegiatan Siswa (LKS)}

Menurut Nana Sujana

(1989:134) LKS berperan sebagai pemandu siswa dalam melaksanakan tugas belajar baik secara idividu maupun kelompok. Azhar (1997:78) mengemukakan bahwa dengan adanya LKS siswa dapat memahami materi pelajaran secara keseluruhan dengan lebih mudah.

Menurut Trianto (2008:148) mengemukakan bahwa LKS adalah panduan siswa yang digunakan untuk melakukan kegiatan penyelidikan atau pemecahan masalah, yaitu merupakan lembaran-lembaran tugas yang dikerjakan oleh siswa.

Menurut Hidayah dalam Setyaningsih (2014: 43), LKS merupakan perangkat pembelajaran sebagai pelengkap atau sarana pendukung pelaksanaan Rencana pembelajaran (RP)

LKS digunakan sebagai penunjang dalam melaksanakan tugas mandiri untuk memahami konsep-konsep yang diajarkan dengan pembelajaran berbasis masalah (PBL) dan pendekatan saintifik pada materi Proklamasi Kemerdekaan. LKS ini berguna bagi siswa sebagai pedoman belajar mandiri dalam kelompok untuk memahami konsep-konsep yang dipelajari. Keuntungan adanya lembar kegiatan adalah bagi guru, memudahkan guru dalam melaksanakan pembelajaran, bagi siswa akan belajar secara mandiri dan belajar memahami dan menjalankan suatu tugas tertulis. Dengan demikian LKS bertujuan untuk mendorong siswa secara aktif dalam proses pembelajaran,dan mengembangkan proses berpikir.

\section{c. Handout}

Menurut Prastowo (2011:79) handout adalah bahan pembelajran yang sangat ringkas. Bahan ajar ini bersumber dari beberapa literatur yang relevan terhadap kompetensi dasar dan materi pokok yang diajarkan kepada peserta didik. Bahan ajar ini diberikan kepada peserta didik guna memudahkan mereka saat mengikuti proses pembelajaran. Dengan demikian bahan ajar ini tentunya bukanlah sesuatu bahan ajar yang mahal, melainkan ekonomis dan praktis

Menurut Badan Pengembangan Akademik Universitas Islam Indonesia (2009) Handout atau HO adalah sesuatu yang diberikan kepada siswa ketika mengikuti kegiatan pembelajaran. HO dimaksudkan untuk memperlancar dan memberikan bantuan informasi atau materi pembelajaran sebagai pegangan bagi mahasiswa

\section{d. Tes Hasil Belajar (THB)}


Perangkat pembelajaran juga dilengkapi dengan alat evaluasi berupa tes hasil belajar yang dapat digunakan untuk mengukur ketuntasan belajar siswa pada materi Proklamasi kemerdekaan Indonesia. Tes hasil belajar yang baik hendaknya dapat mengukur apa yang dipelajari sesuai dengan indikator. Penyusunan tes hasil belajar harus mewakili materi yang telah dipelajari dan disusun sesuai dengan tujuan penggunaan tes itu sendiri. Dalam penelitian ini tes yang digunakan berbentuk tes uraian. Secara umum tes uraian adalah pertanyaan yang menuntut siswa menjawab dalam bentuk menguraikan, menjelaskan, mendiskusikan, memberi alasan, dan bentuk lain yang sejenis sesuai dengan tuntutan pertanyaan dengan mengunakan kata-kata dan bahasa sendiri.

\section{METODE PENELITIAN}

Desain Penelitian yang digunakan dalam penelitian ini adalah Model Four-D dari Thiagarajan, Semmel dan Semmel. Namun pelaksanaanya dimodifikasi hanya sampai pada tahap III, yaitu tahap pendefinisian (Define), tahap perancangan (Design), dan tahap pengembangan (Develop)

Pada tahap pendahuluan populasi dari penelitian ini adalah kelas XI sedangkan sample penelitian diambil kelas XI DKV-1 dan kelas XI DKV-2, pemilihan ini didasarkan pada hasil nilai ulangan UTS dan UAS, yang mempunyai kesetaraan nilai.sedangkan Subjek penelitian adalah guru pengajar dan dua kelas XI yaitu siswa kelas XI DKV-1 yang berjumlah 24 siswa yang terdiri dari 9 putri 15 putra dan kelas XI DKV-2 yang berjumlah siswa 30 orang yang terdiri dari 20 putri dan 10 putra SMK Negeri 12 Surabaya tahun ajaran 2014/2015.

Pada tahap perancangan dalam penelitian ini kelas XI DKV 1 sebagai kelas control yaitu kelas yang tidak diberikan perlakuan model Problem Based Learning sedangkan kelas XI DKV 2 sebagai kelas eksperimen yaitu kelas yang mendapatkan perlakuan model Problem Based Learning. Dengan pengaturan kondisi kelas tersebut, penelitian ini dapat menghasilkan pengukuran hasil pengembangan perangkat pembelajaran secara tepat.

Teknik analisis data yang digunakan dalam penelitian ini, pertama dengan menggunakan deskriptif kualitatif dilaksanakan pada tahap pendahuluan, perancangan dan pengembangan, validasi, dan uji empiri pada pelaksanaan pembelajaran. Kedua teknik analisis data menggunakan deskriptif kuantitatif dilaksanakan pada uji empiris hasil belajar dan respon siswa.

\section{HASIL DAN PEMBAHASAN}

Hasil validasi RPP dapat dilihat pada tabel 4.2 dan skor hasil validasi perangkat RPP pada masingmasing komponen berkategori baik dengan rata-rata skor sebesar 3,39 . Hal ini dapat dinyatakan bahwa RPP yang telah dibuat sudah sesuai dengan indikator pembelajaran yang akan dicapai siswa, sehingga RPP valid dan layak untuk digunakan

Hasil validasi Lembar Kerja Siswa (LKS) dapat dilihat pada tabel 4.3 dan skor hasil validasi perangkat Lembar Kerja Siswa (LKS) pada masing-masing komponen berkategori baik dengan rata-rata skor sebesar 3,56. Hal ini dapat 
dinyatakan bahwa Lembar Kerja Siswa (LKS) yang telah dibuat sudah sesuai dengan indikator pembelajaran yang akan dicapai siswa, sehingga Lembar Kerja Siswa (LKS) valid dan layak untuk digunakan.

Hasil validasi Handout dapat dilihat pada tabel 4.4 dan skor hasil validasi perangkat Handout pada masing-masing komponen berkategori baik dengan rata-rata skor sebesar 3,70. Hal ini dapat dinyatakan bahwa Handout yang telah dibuat sudah sesuai dengan indikator pembelajaran yang akan dicapai siswa, sehingga Handout valid dan layak untuk digunakan

\section{Pelaksanaan Pembelajaran Sejarah dengan Model Problem Based Learning dengan Pendekatan Saintifik Berdasarkan Analisis Deskriptif.}

Pelaksanaan pembelajaran dalam proses pembelajaran, yang telah dianalisis secara deskriptif menunjukkan bahwa nilai rata-rata yang diperoleh dalam pelaksanaan pembelajaran adalah 3,3. Nilai ini sudah mencapai kriteria baik Hal ini berarti pelaksanaan pembelajaran Sejarah dengan model problem based learning dengan pendekatan saintifik adalah baik.

\section{Hasil Penelitian Hasil Belajar Siswa Setelah Menggunakan Model Problem Based Learning dengan Pendekatan Saintifik Berdasarkan Analisis Deskriptif.}

Hasil belajar siswa setelah menggunakan model problem based learning dapat dilihat pada masingmasing kompetensi yaitu sikap (spiritual dan sosial), sikap pengetahuan dan sikap spiritual.
Pada sikap spiritual sudah menujukkan sikap spiritual yang baik. Pada sikap sosial sudah menunjukkan kategori baik mencapai skor rata-rata 3,6. Pada kompetensi pengetahuan dapat dilihat dari hasil pengerjaan soal pre-test dan posttest. Pada kelas eksperimen yang dilakukan oleh kelas XI DKV-2 terjadi peningkatan dari rat-rata skor hasil pre-test yaitu 58,9 dengan ketuntasan belajar 3,3\% meningkat pada hasil post-test mencapai ratarata skor 78 dengan ketuntasan belajar mencapai 83,3\%. Pada kelas kontrol yang dilakukan oleh kelas XI DKV-1, hasil rata-rata skor pre-test mencapai 60,7 dengan ketuntasan belajar mencapai $8,3 \%$ terjadi peningkatan hasil belajar lebih rendah daripada kelas eksperimen yaitu mencapai rata-rata skor hasil post-test 73,6 dengan ketuntasan belajar mencapai 58,3\%

Berdasarkan pengujian hasil output dengan SPSS.16 Kolmogorov Smirnov test pada soal pre-test diperoleh nilai Asymp Sig. Ialah $0,167>0,05$ untuk kelas eksperimen (XI DKV-2) dan untuk kelas kontrol ialah 0,200 >0,05. Sedangkan hasil output dengan SPSS.16 Kolmogorov Smirnov test pada soal post-test diperoleh nilai Asymp Sig. Ialah $0,118>0,05$ untuk kelas eksperimen (XI DKV-2) dan untuk kelas kontrol ialah $0,200>0,05$. Hasil ini menunjukkan bahwa data hasil pretest dan post-test berdistribusi normal. Hasil output dengan SPSS.16

Hasil belajar kelas eksperimen (XI DKV-2) meningkat daripada kelas kontrol (XI DKV-1) disebabkan adanya perlakuan model pembelajaran problem based learning dengan pendekatan saintifik pada kelas XI DKV-2. Hasil uji $t$ 
berpasangan pada kelas pre-test dan post-test memperoleh Sig (2-tailed) adalah 0,000 . Hal ini menunjukkan bahwa adanya perbedaan skor pretest dan post-test yang signifikan, sehingga pembelajaran Sejarah menggunakan model problem based learning efektif dalam meningkatkan hasil belajar siswa.

Pada kompetensi ketrampilan juga menunjukkan kategori baik pada keterampilan diskusi dengan mencapai rata-rata skor 2,88 sedangkan pada keterampilan presentasi mencapai rata-rata skor 3,4 .

\section{Aktivitas Siswa Berdasarkan Analisis Deskriptif}

Berdasarkan hasil analisis deskriptif tentang aktivitas siswa, diperoleh kesipulan bahwa aktivitas siswa dalam pembelajaran baik. Aspek-aspek yang diamati meliputi: melakukan pengamatan, membuat pertanyaan, Mengumpulkan data/eksperimen/mengerjakan LKS, mengolah informasi dari hasil eksperimen, menyampaikan hasil pengamatan dan kesimpulan

Dari aspek-aspek tentang rekapitulasi aktivitas siswa selama pembelajaran. menunjukkan bahwa aktivitas siswa pada uji empiris di kelas dikategorikan baik. Hal ini dikarenakan dari hasil pengamatan menunjukkan bahwa setiap aspek aktivitas siswa untuk semua rencana pelaksanaan pembelajaran (RPP) menacapai skor 3,4 .

\section{Diskusi Hasil Penelitian Respon Siswa Berdasarkan Analisis Deskriptif \\ Berdasarkan analisis deskriptif hasil angket siswa menunjukkan bahwa respon siswa terhadap pembelajaran Sejarah}

menggunakan model pembelajaran problem based learning tergolong baik, yaitu respon siswa terhadap semua aspek berada di atas $80 \%$.. Minat positif dari siswa akan membuat siswa antusias untuk belajar, sehingga siswa diharapkan dapat memperoleh hasil belajar yang baik. Pendapat siswa terhadap bahasa yang digunakan dalam lembar kerja siswa, dengan langkah-langkah pembelajaran problem based learning dan tes hasil belajar sebagian besar menyatakan jelas dan tertarik.

\section{KESIMPULAN}

Berdasarkan hasil validasi RPP dan skor hasil validasi perangkat RPP pada masing-masing komponen berkategori baik dengan rata-rata skor sebesar 3,39.

Hasil validasi Lembar Kerja Siswa (LKS) dan skor hasil validasi perangkat Lembar Kerja Siswa (LKS) pada masing-masing komponen berkategori baik dengan rata-rata skor sebesar 3,56.

Hasil validasi Handout dan skor hasil validasi perangkat Handout pada masing-masing komponen berkategori baik dengan rata-rata skor sebesar 3,70. Hal ini dapat dinyatakan bahwa Handout yang telah dibuat sudah sesuai dengan indikator pembelajaran yang akan dicapai siswa, sehingga Handout valid dan layak untuk digunakan

Hasil validasi Tes Hasil Belajar (pre-test dan post-test) dan skor hasil validasi Tes Hasil Belajar (pre-test dan post-test) pada masingmasing komponen berkategori baik dengan rata-rata skor sebesar 3,78.

Berdasarkan hasil pengamatan pelaksanaan dalam 
proses pembelajaran, yang telah dianalisis secara deskriptif menunjukkan bahwa nilai rata-rata yang diperoleh dalam pelaksanaan pembelajaran adalah 3,3. Nilai ini sudah mencapai kriteria baik.

Pada sikap spiritual sudah menujukkan sikap spiritual yang baik.. Pada sikap sosial sudah menunjukkan kategori baik mencapai skor rata-rata 3.

Pada kompetensi pengetahuan dapat dilihat dari hasil pengerjaan soal pre-test dan posttest. Pada kelas eksperimen yang dilakukan oleh kelas XI DKV-2 terjadi peningkatan dari rat-rata skor hasil pre-test yaitu 58,9 dengan ketuntasan belajar 3,3\% meningkat pada hasil post-test mencapai ratarata skor 78 dengan ketuntasan belajar mencapai $83,3 \%$. Pada kelas kontrol yang dilakukan oleh kelas XI DKV-1, hasil rata-rata skor pre-test mencapai 60,7 dengan ketuntasan belajar mencapai $8,3 \%$ terjadi peningkatan hasil belajar lebih rendah daripada kelas eksperimen yaitu mencapai rata-rata skor hasil post-test 73,6 dengan ketuntasan belajar mencapai 58,3\%

Hasil belajar kelas eksperimen (XI DKV-2) meningkat daripada kelas kontrol (XI DKV-1) disebabkan adanya perlakuan model pembelajaran problem based learning dengan pendekatan saintifik pada kelas XI DKV-2. Hasil uji $t$ berpasangan pada kelas pre-test dan post-test memperoleh Sig (2-tailed) adalah 0,000. Hal ini menunjukkan bahwa adanya perbedaan skor pretest dan post-test yang signifikan, sehingga pembelajaran Sejarah menggunakan model problem based learning efektif dalam meningkatkan hasil belajar siswa.

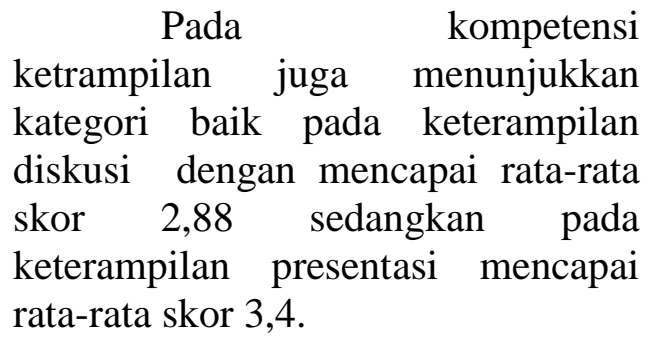

\section{DAFTAR PUSTAKA}

Aedy, H. H. 2009. Karya agung sang guru sejati. Bandung: Alfabeta.

Arends, Richard I. 1997. Classroom Instruction and Management. New York: Mc Graw-Hill Companies, Inc.

Ali, R., Akhter, A., Shahzad, S., Sultana, N., \& Ramzan, M. 2011. The impact of motivation on students' academic achievement in mathematics in problem basedlearning environment. International Journal of Academic Research. 3 (1). 306- 309.

Arends, Richard I. 2008. Learning To Teach. Yogyakarta: Pustaka Pelajar

Arikunto, S. 2006. Prosedur Penelitian. Jakarta: Rineka Cipta.

Beckmann, A et al. 2009. The ScienceMath Project. Germany: The ScienceMath-Group. 
Depdiknas. 2006e. Panduan Pengembangan Rencana Pelaksanaan Pembelajaran Sekolah Menengah Pertama Mata Pelajaran Ilmu Pengetahuan Alam. Jakarta: Dirjen Dikdasmen.

Djamarah, Saiful, B. 2002. Psikologi Belajar. Jakarta: Rineka Cipta

Dyahwati, 2013. Pengembangan Perangkat Pembelajaran Berbasis Masalah pada Materi Sistem Pencernakan Makanan Bervisi Pendidikan Karakter.Jurnal Unnes Vol2 no 12013. http://journal.unnes.ac.id/sju

Hamalik, Oemar. 1990. Metode Belajar dan KesulitanKesulitan Belajar. Bandung: Tarsito

Hamalik, Oemar. 1995. Kurikulum dan Pembelajaran. Jakarta, Bumi Aksara

Hodson, D. (1996). Laboratory work as scientific method: Three decades of confusion and distortion. Journal of Curriculum Studies, 28(2), 115-135.

Ibrahim, Muslimin, dkk. 2000. Pembelajaran Kooperatif. Surabaya: Unesa University Press.

Ibrahim Muslimin dan Nur Mohamad.,2000.

Pengajaran Berdasarkan Masalah : Universitas Negeri Surabaya
Isjoni. 2010. Cooperative Learning. Efektifitas Pembelajaran Kelompok. Bandung: Alfabeta.

Isjoni . 2007. Pembelajaran Sejarah . Bandung : Alfabeta

Kemdikbud. 2013. Pendekatan Scientific (Ilmiah) dalam Pembelajaran . Jakarta: Pusbangprodik.

Kemdikbud. 2013. Pengembangan Kurikulum 2013. Paparan Mendikbud dalam Sosialisasi Kurikulum 2013. Jakarta :Kemdikbud

Kristiana, D. 2013. Implementasi Model Pembelajaran Berbasis Masalah dengan Menggunakan LKS Untuk mencapai Penguasaan Ketrampilan Berpikir Kritis Siswa Pada Mata Pelajaran IPS. Tesis. Universitas Negeri Surabaya

Majid, Abdul. 2007. Perencanaan Pembelajaran: Mengembangkan Kompetensi Guru. Bandung: Rosdakarya

Mohamad Nur, Prof. Dr. 2008. Model Pembelajaran Berdasarkan Masalah. Surabaya : Universitas Negeri Surabaya.

Mustaji, dkk. 2005. Pembelajaran Berbasis Konstruktivistk. Surabaya: Unesa University Press. 
Permendikbud RI nomor 81 A. 2013. Implementasi Kurikulum Pedoman umum Pembelajaran

Slavin, Robert E. 1995. Cooperative Learning. Theory, Research and Practice, Second Edition. Boston: Allyn and Bacon.

Sulistyowati, Pengembangan perangkat pembelajaran model problem based learning (PBL) dipadu dengan pendekatan savi pada materianalisis enzim hati. Jurnal FKIP UNS, Vol 1, no.1 (2014)

Sudjana, N. 2006 Penilaian Hasil Proses Belajar Mengajar. Bandung: Rosdakarya

Tegeh, I M. 2009. Perbandingan prestasi belajar mahasiswa yang diajar dengan

menggunakan problembased learning dan ekspositori yang memiliki gaya kognitif berbeda.
Desertasi: Universitas

Negeri Malang Program

Pasca Sarjana PSSJ

Teknologi Pembelajaran.

Thiagarajan, S. Semmel.D.S, and Semmel.M.I. 1974, Instructional Developmrnt for Training Teacher of Exeptional Children, Minnepolis, Indiana University.

Trianto. 2010. Mendesain Model Pembelajaran Inovatif Progresif. Jakarta: Kencana.

Vogotsky, L.S. 1978. Mind In Society: The Development Of Higher Psychological Processes. London : Cambridge University Press. 